Meta

Journal des traducteurs

Translators' Journal

\title{
CTIC conférence
}

\section{Jean-Paul Vinay et Daniel Gile}

Volume 32, numéro 4, décembre 1987

URI : https://id.erudit.org/iderudit/002441ar

DOI : https://doi.org/10.7202/002441ar

Aller au sommaire du numéro

Éditeur(s)

Les Presses de l'Université de Montréal

ISSN

0026-0452 (imprimé)

1492-1421 (numérique)

Découvrir la revue

Citer cette note

Vinay, J.-P. \& Gile, D. (1987). CTIC conférence. Meta, 32(4), 503-505.

https://doi.org/10.7202/002441ar

Ce document est protégé par la loi sur le droit d'auteur. L'utilisation des services d'Érudit (y compris la reproduction) est assujettie à sa politique d'utilisation que vous pouvez consulter en ligne.

https://apropos.erudit.org/fr/usagers/politique-dutilisation/
Cet article est diffusé et préservé par Érudit.

Érudit est un consortium interuniversitaire sans but lucratif composé de l'Université de Montréal, l'Université Laval et l'Université du Québec à Montréal. Il a pour mission la promotion et la valorisation de la recherche. https://www.erudit.org/fr/ 


\section{CTIC CONFERENCE}

"A Profession at the Service of the Country" was the theme of the first Conference of the Canadian Translators and interpreters Council (CTIC), held at the Westin Hotel in Ottawa, October 29-31, 1987. The Conference, chaired by Michel Limbos, CTIC President, was a resounding success, attracting some $\mathbf{4 5 0}$ language professionals from every region of Canada and from abroad.

"Canada is a nation that has welcomed many immigrants, and translation has been an essential aspect of Canadian life since the founding of the country... In such a context", stated Alain Landry, Assistant Under Secretary of State for Official Languages and Translation, where two great official language groups are in constant contact, in addition to a host of other cultures, it is only natural that (translation) should play an extremely important role". CTIC is aware of this importance and, from the outset; has adopted the mandate of bringing together translators, interpreters and terminologists from all parts of Canada with a view to promoting professional conduct and standards throughout the country. This year, for the first time, these professionals had an opportunity to meet and become better acquainted. Among the many personalities participating in this event were Alain Landry, representing Secretary of State David Crombie, Commissioner of Official Languages D'Iberville Fortier and Kurt Gingold, representing the International Federation of Translators.

The program was divided into four parts. The Profession - An Overview enabled representatives of the various provincial associations to introduce themselves and describe the situation in their region. Special attention was given to those working in the Amerindian and Inuit languages, who are in the pro- 
cess of forming professional associations and whose activity is too often overlooked.

Facets of the Profession illustrated the diversity of translation activities and the profession's capacity to adapt to new realities. These sessions dealt with conference, visual language and court interpreting, technical communication, terminology and, of course, applications of computer technology.

The section on Areas of Specialization emphasized the fact that translators play a part in all fields of human endeavour, in all forms of communication and in all languages.

The final section, entitled Training, dealt with one of the main concerns of the profession : ensuring competent professionals for tomorrow.

One of the conference press releases, entitled Translators of the year 2000: professionals of the wired world bore witness to a continuing concern of many speakers - the changes and challenges to be faced by the profession in coming years.

\section{Highlights}

In addition to the program of worshops and plenary sessions, the Conference featured two landmark events in the history of the translation profession in Canada. The first was the official launching of Professor Jean Delisle's, la Traduction au Canada/ Translation in Canada, 1534-1984. The second, at the closing session of the Conference, was the presentation of the first CTIC Prize to Jean-François Joly, to whom the following tribute was paid;

The first conference of the Canadian Translators and Interpreters Council would up on Saturday, October 31 . During the final session, the newly created CTIC Prize was presented to Jean-François Joly, Canada's representative on the Council of the International Federation of Translators and head of language services with the Canadian Institute of Chartered Accountants in Montreal.

The CTIC Prize is awarded to persons who have made an outstanding contribution to the profession in Canada. As a member of the council of the Société des traducteurs du Québec (STQ) and later as STQ president, Mr. Joly was an extremely active promoter of professional recognition in Quebec, and participated in founding the terminologists' and conference interpreters' sections of the STQ. $\mathrm{He}$ was also interested in the standard $\mathrm{Ca}$ nada-wide certification examination, which has now been adopted by all the provincial associations and is administered by CTIC.

As president of CTIC from 1983 to 1986 , Jean-François was instrumental in publicizing the role of Canada's language professionals both nationally and internationally. $\mathrm{He}$ is one of the founders of the FIT Regional
Centre for North America, which includes Canada, the United States and Mexico.

Mr. Joly was one of Canada's official delegates to the last FIT conference in Holland in August 1987 and was elected to the council of the international body, thus enabling him to continue his work of promoting the profession and Canada's contribution to the language field.

A welcome innovation for many of the participants attending the Conference was the distribution of the Proceedings as the event came to a close. The members of the Organizing Committee are to be congratulated on their fine work in providing such a rewarding experience for Canadian language professionals and their guests.

[With thanks to S.T.I.B.C. President, Dr.

Phyllis Wrenn, and The TRANSLetter.]

The Canadian Translators and Interpreters Council (CTIC) is also pleased to announce its new executive, elected recently at its annual meeting, held in Ottawa, October 31 and November 1, 1987, following the first CTIC Conference. Those elected were :

President : Michel Limbos, Association of Translators and Interpreters of Ontario (ATIO)

Vice-President : Yves King, Corporation des traducteurs et interprètes du Nouveau-Brunswick (CTINB)

Secretary-Treasurer : Mary Plaice, Société des traducteurs du Québec (STQ)

Michel Limbos, a certified translator and interpreter of ATIO and an associate member of the American Translators Association (ATA), is Manager of Translation for the Export Development Corporation in Ottawa. He was elected president of CTIC for a second year. In his first year, he was head of the official Canadian delegation to the 11th World Congress of the International Federation of Translators held in Maastricht, where he was unanimously elected chairman of the committee entrusted with the delicate task of assessing whether a South African association was eligible for FIT membership. In particular, over the past two years, Mr. Limbos chaired the organizing committee for the first CTIC Conference. Like his predecessor, Jean-François Joly, he is a member of the organizing committee for the second conference of the FIT Regional Centre for North America, which will take place in Boston in 1989.

Yves King is a certified member and president of CTINB, and has represented his association on CTIC since 1983. He is currently employed by the New Brunswick Government translation bureau. During his terms as president of CTINB, his objective has been to increase membership in the Corporation, make it more attractive to members, and promote Equivalence, a publication whose high quality transcends its modest appearance. The success of the conference organized by CTINB and held last spring 
in Fredericton bears witness to the achievement of his goals. He succeed Betty Cohen of STQ.

Mary Plaice, in charge of English services for the language firm $\mathrm{La}$ langagerie after many years with the Quebec government, is a certified translator, associate terminologist and president of STQ. She too is an associate member of ATA. She was an official CTIC delegate to the FIT congresses held in Vienna and Maastricht, and chaired the awards committee for the first North American Conference and for the recent CTIC Conference. She succeeds
Nicolle Sauvage of the Association of Translators and Interpreters of Saskatchewan (ATIS).

CTIC is a federation of seven provincial professional associations representing some 2500 translators, interpreters and terminologists. It has member societies located in British Columbia (STIBC), Alberta (AATI), Saskatchewan (ATIS), Manitoba (ATIM), Ontario (ATIO), Quebec (STQ), and New Brunswick (CTINB). CTIC is the only Canadian member association of FIT, where it is represented on Council by immediate past president JeanFrançois Joly. 